\title{
Family Involvement in Middle Management and Its Impact on the Labor Productivity of Family Firms
}

\author{
Qiongjing $\mathbf{H u},{ }^{1}$ Yanlong Zhang, ${ }^{1}$ and Jingjing $\mathbf{Y a o}^{2}$ \\ ${ }^{1}$ Peking University, China, and ${ }^{2}$ IÉSEG School of Management (LEM-CNRS 9221), France
}

\begin{abstract}
Family business owners and researchers tend to overwhelmingly focus on the top-level structure of firms but ignore the middle-level practice - involving family members in the middle-management team. Compared to top managers at the strategic apex, middle-level managers are mainly responsible for internal operations and control, and the composition of the middle-management team has an immediate and direct impact on the overall workforce efficiency of family firms. Integrating agency theory and organizational justice perspective, we proposed that family involvement in middle management would have a negative impact on the labor productivity of family firms. We further corroborated this effect by identifying three boundary conditions at the individual (i.e., familial CEO), organizational (i.e., firm size), and regional (i.e., labor mobility) levels. Using a sample of 1,284 privately owned family firms in China, we found that family involvement in middle management, measured as the percentage of familial middle-level managers, was negatively associated with labor productivity. Furthermore, this negative relationship existed only when the CEO is a family member rather than a professional manager, when the size of the firm is large rather than small, or when the firm is located in regions with low rather than high labor mobility. These findings contribute to family business literature and provide practical implications for human resource management in family firms.
\end{abstract}

KEYWORDS family involvement, labor productivity, middle management, multilevel

\section{INTRODUGTION}

Family businesses play an active and pivotal role in global economic growth (Claessens, Djankov, Fan, \& Lang, 2002; Harris, Martinez, \& Ward, 1994). In emerging economies, family businesses are particularly important because they show stronger dynamics and versatilities (Whyte, 1996), perform unique tasks such as wealth preservation (Carney, 2007), and account for a higher proportion of national economic growth (Claessens, Djankov, \& Lang, 2000). For example, there are nearly eight million private enterprises in China, and more than eighty percent of those are family businesses (Steen \& Baldwin, 2015). One of the defining

Corresponding author: Yanlong Zhang (yanlong.zhang@gsm.pku.edu.cn) 
characteristics of family firms is a high level of family involvement, which reflects the family influence on the firms' strategic decision making and daily operation management. Scholars have a fueling interest in family involvement because this striking nature of family business greatly affects firm outcomes (Anderson \& Reeb, 2004; Sciascia \& Mazzola, 2008). In emerging markets, due to the market volatility and policy instability, family involvement may show some slightly different characteristics such as more nepotism (Khwaja \& Mian, 2005), so in this study we pay particular attention to family involvement in emerging markets.

The literature has specified family involvement in three forms: family ownership (e.g., Anderson \& Reeb, 2004; Chu, 2011; De Massis, Kotlar, Campopiano, \& Cassia, 2015; Tsao, Chen, Lin, \& Hyde, 2009; Yammeesri \& Lodh, 2004), family control (e.g., Barontini \& Caprio, 2006; Silva \& Majluf, 2008), and family management (e.g., Chang \& Shim, 2016; De Massis et al., 2015; Ensley, \& Pearson, 2005). While extant studies have adequately examined the influence of family involvement from an upper-echelon perspective by focusing on the organizations' high level such as firms' ownership structure, board composition, and top management team, our understanding of the influence of family involvement at the middle-level, i.e., family members occupying middle-level managerial positions, remains inadequate. Shifting our focus to the middle-level managers is theoretically important because they serve as communication channels bridging lower-level employees and the top management team. They collect information from the bottom of the organization and meanwhile translate strategies defined at higher levels into downward actions (Fenton-O'Creevy, 1998; Floyd \& Wooldridge, 1994; Guth \& Macmillan, 1986). Overall, middle-level managers are in charge of carrying out firm polices, supervising frontline employees, taking responsibility of internal operations and control, so they are more likely to influence firm efficiency (Bartlett \& Ghoshal, 1993).

Filling middle-level managerial positions with family members is a common practice among family firms in which firm owners have more discretion regarding personnel issues and nepotism (employing family members) is tolerated or understood (Birley, 2001). In these firms, family members' participation in managerial activities has a direct impact on the firm's internal management. That said, although family involvement at both top- and middle-level management has important impacts on a firm's operation and performance, the mechanisms through which these two management bodies at different levels affect a firm's managerial outcomes can differ greatly. Therefore, investigating the influence of the degree of family involvement in middle-level management supplements our understanding of the influence of family involvement on firms' performance, and has important managerial implications for human resource practices in family firms.

To address this issue, we borrowed insights from agency theory (Jensen \& Meckling, 1976) and organizational justice perspective (Colquitt, 2001; Colquitt et al., 2013) to examine how family involvement in middle management 
(i.e., percentage of family middle managers in the middle management team) leads to distinctive agency problems, exerting a negative influence on a firm's labor productivity. This is a primary indicator of overall workforce performance that has more proximate relation with the functions of middle-level management (e.g., carrying out daily operations, monitoring and motivating employees, and so on) (Delery \& Shaw, 2001). Using a sample of Chinese privately owned family firms, we found that family involvement in middle management was negatively related to the labor productivity of family firms. Moreover, we adopted a multilevel approach to understanding the boundary conditions of this effect. In particular, we examined the moderation effects of three contextual factors at different levels familial CEO (individual level), firm size (organizational level), and labor mobility (regional level). We found that the negative impact of family involvement in middle management on family firms' labor productivity existed only when the CEO was a family member, or when family firms were large in size, or when family firms were located in regions with low labor mobility.

These findings make several contributions to the literature on family businesses. First, we expand the scope of family involvement research by supplementing the upper-echelon perspective with a new focus on middle-level management, and investigated this important but underexplored form of family involvement. Our results indicate that middle managers and top-level decision makers differ in their roles in family firms. By examining the impact of the proportion of family members among middle managers, we enrich our understanding of the impacts of family involvement. Second, by integrating the organizational justice perspective with agency theory, we offer a new angle for understanding the phenomenon of family involvement. In this way we contribute to organizational justice by extending a micro theory into a more macro phenomenon, which is a meaningful attempt at micro-macro integration. Third, we introduce multilevel contextual factors in moderating the relationship between family involvement in middle management and family firms' labor productivity. By taking individual-, organizational-, and regional-level characteristics into consideration, we present a more-comprehensive understanding of when appointing family members as middle managers will be more or less detrimental. In addition, our findings have important managerial implications for human resource practices in privately owned family firms. We reveal that nepotism is harmful overall when selecting middle managers but only holds in certain conditions.

\section{THEORETICAL BACKGROUND AND HYPOTHESES}

\section{Agency Theory, Organizational Justice, and Family Involvement}

Agency theory has been widely quoted in explaining how family involvement affects firm performance (Dyer, 2006; Jensen \& Meckling, 1976; Karra, Tracey, \& Phillips, 2006). Agency theory suggests that when the principals and agents of 
the firm are different, agents may engage in activities that, if unchecked, will hurt the principals' interests due to information asymmetries and self-interest incentives (Jensen \& Meckling, 1976). Some scholars suggest that family involvement is an effective way to reduce agency cost because it will align the principal-agent goals, build high trust and shared values, facilitate communication and cooperation among owners and family agents, and hence benefit the performance of family business (e.g., Anderson \& Reeb, 2003; Daily \& Dollinger, 1992; McConaughy, Matthews, \& Fialko, 2001). However, this is not always the case. Other studies have demonstrated that family involvement actually exposes family firms to unique agency problems that are even more difficult to resolve due to family relations (Gomez-Mejia, Nunez-Nickel, \& Gutierrez, 2001; Schulze, Lubatkin, Dino, \& Buchholtz, 2001). For example, goal incongruence between owners and family agents still exist. Also, adverse selection and shirking are likely to originate from altruism towards family members. Overall, these studies indicate that agency problems in family firms may come in a variety of forms, which are detrimental to firm performance. The current research focuses on one particular form of family involvement - family involvement in middle management - and suggests that distinctive agency threats will occur with an increase in the family middle managers.

In addition, we also integrate the organizational justice perspective (Colquitt, 2001; Colquitt et al., 2013) to clarify how family involvement in middle management impacts labor productivity by influencing nonfamily employees' perception of justice. We integrate this perspective to elaborate on the additional performance threat caused by family middle managers for the following reasons. First, justice is an important organizational factor that directly influences employees' behavior. The perception of justice fosters employees' social exchange quality with organizations, and thereby enhances their task performance as well as stimulates their organizational citizenship behavior (Colquitt et al., 2013). In contrast, a low level of justice perception is likely to incur negative consequences, such as low social-exchange quality and negative job attitudes. Creating organizational justice may be the key to effective management of nonfamily employees, which has been recognized as a critical issue in family firms (Barnett \& Kellermanns, 2006; Chua, Chrisman, \& Sharma, 2003). Second, compared to top managers, middle managers have much more frequent interactions with frontline employees through daily supervision, and thus have a more-direct influence on employees' work attitude, motivation, and behavior. As far as justice is concerned, middle managers may be an influential factor in employees' justice perception. Third, in family firms, the violation of justice may be a ramification of family ties (Barnett \& Kellermanns, 2006). Family involvement in middle management could thus amplify the salience of organizational injustice, or in other words increase nonfamily members' perception of injustice. Overall, integrating the organizational justice perspective in order to study the middle-level management team is well-founded and offers additional 
explanations for the effect on labor productivity of family involvement in middle management.

\section{The Main Effect of Family Involvement in Middle Management}

A central feature of the middle-level managerial position is that it serves as the intermediate level in the firm, just like 'the filling in the sandwich' (McConville \& Holden, 1999). Middle managers are responsible for the performance of their departments; in doing so, they need to motivate team members to accomplish various tasks on a daily basis (Schulze et al., 2001). This suggests that middle managers find themselves involved in frequent social interactions with both the top management team and lower-level employees in the firm. By analyzing the role of middle managers in these two types of social interactions, we argue that family involvement in middle management may bring unexpected disadvantages to family firms' labor productivity.

The first type of social interaction occurs between middle-level managers and higher-level managers. Extending agency theory, we anticipate an increase of agency cost, because the owners may assign the middle-level positions to unqualified family members due to nepotism (Ewing, 1965). According to socialemotional wealth theory, families usually have noneconomic goals in addition to economic considerations, such as providing employment for family members and enhancing family cohesion (Cennamo, Berrone, Cruz, \& Gomez-Mejia, 2012). However, family firms usually have a limited labor pool; this implies that the family is unable to provide enough qualified members to manage key operations (Dyer, 2006). Under such circumstances, the more family members that are hired as middle managers, the less competent the middle management team will be, thus leading to additional coaching and monitoring costs. Besides, compared to nonfamily members, family middle managers probably capitalize on family ties to gain more leader support and superior organizational resources, but they are less vulnerable to criticism or layoffs when they make mistakes, as they are protected under the umbrella of family ties. That is, the reward and punishment system is biased by family ties and thus will be less effective in holding family managers accountable. Therefore, with the increase of family members occupying middlelevel managerial positions, the accountability of the middle management team decreases, thus harming the labor productivity of family firms.

The second type of social interaction occurs between middle-level managers and lower-level employees. Middle managers have to supervise the frontline employees, and their unique family member identity jeopardizes employees' work motivation. In family firms, the owners usually have the power to influence crucial personnel selection decisions. They may hire family members as managers to create jobs for the family, or to perpetuate family control across generations (Chua, Chrisman, \& Steier, 2003; Jaskiewicz \& Uhlenbruck, 2013). In this case, family identity rather than competency is the key determinant of entering the management team. This 
evaluation and selection process appears to be unfair to nonfamily employees and thus weakens their motivation to seek career advancement within the firm. Studies show that nonfamily employees believe more strongly than family employees that a family member will take over the firm and they will be excluded from senior positions (e.g., Poza, Alfred, \& Maheshawi, 1997). Poza and colleagues (1997) present evidence that nonfamily managers are less satisfied than family managers with the equity of compensation and how their firms handle growth. In other words, the fact that family members occupy important managerial positions sends the negative signal to employees that their promotion will be less likely. This is a dangerous signal because it affects how employees perceive justice within the organization. A positive perception of justice has been recognized as a critical issue to family businesses (Barnett \& Kellermanns, 2006; Chua et al., 2003), because it fosters employees' social exchange quality with organizations, and thereby enhances their task performance, as well as stimulates organizational citizenship behaviors (Colquitt et al., 2013). Therefore, from the organizational justice perspective, family members' involvement in middle management jeopardizes nonfamily employees' perception of justice, and consequently diminishes their work efforts.

In sum, family involvement in middle-level managerial positions contradicts the firm's economic goal and reduces nonfamily employees' work motivation. The higher the percentage of family managers in the middle management team, the less effective the middle management team will be and the more pronounced nonfamily employees' perception of organizational injustice. Thus, we propose that:

Hypothesis 1: Family involvement in middle management will be negatively associated with family firms' labor productivity.

\section{Gontextual Contingencies}

In emerging markets, organizations are nested in a rapidly changing environment, so how organizations' internal practices influence firm outcomes depends on various contextual contingencies. Although emerging markets constitute a major growth opportunity, they are also experiencing domestic policy instability, market orientation conflicts, and financial volatility (Arnold \& Quelch, 1998; Bourgeois, 1985). In these unstable and less-predictable situations, it is particularly necessary to incorporate a contingency perspective to understand how contextual contingencies play a role (Fredrickson \& Mitchell, 1984; Lee \& Miller, 1996). We argue that while family involvement in middle management may endanger labor productivity of the family firms by compromising economic objectives and spreading injustice perception, such negative influence may be especially potent or weak across firms under different contingencies. In the following sections we examine contingencies at the individual (familial CEO), organizational (firm size), 
and regional (labor mobility) levels to add insights into how family involvement in middle management plays a role under different circumstances. We focus on these three contingencies to adopt a multi-level approach to revealing when family involvement in middle management is more problematic and when it is less of an issue. More importantly, we aim to strengthen our arguments that the negative consequence of family middle managers is based on family ties, becomes salient when it disrupts organizational justice, and harms firm performance by decreasing the motivation of nonfamily employees.

\section{Individual Contingency: Familial GEO}

The type and quality of relations between top management and middle management may condition the effectiveness of the middle management. The existence of family ties between top and middle management may exert a moderating influence on the relationship between a share of family middle managers and family firms' labor productivity. In social interactions with the $\mathrm{CEO}$, middle managers must follow instructions from the $\mathrm{CEO}$, and report to the CEO their daily operation and management. However, when the CEO is a family member instead of a professional nonfamily manager, a direct supervisor-subordinate relationship between family members is established. Family middle managers thus may get a free ride or get away with mistakes due to their family ties with the familial CEO (Bruce \& Waldman, 1990). In this sense, with the family members occupying middle-level managerial positions, the familial CEO will not be able to effectively supervise the middle management team.

Moreover, employees tend to consider family management as nepotism and perceive injustice when they observe the family relationship between the CEO and the middle managers. The firm's daily operations and management require frequent social interactions between the $\mathrm{CEO}$ and the middle managers, increasing chances that the familial CEO will demonstrate behaviors that are seemingly more favorable to family members than nonfamily employees (Lee, Lim, \& Lim, 2003). For instance, the familial CEO may delegate more-valuable resources to family middle managers out of altruism but be reluctant to punish poor family middle managers, particularly when such punishment has negative spillover effects on their family relationships outside the firm (Schulze, Lubatkin, \& Dino, 2003).

Taken together, we thus expect that the negative impact of family involvement in middle management on family firms' labor productivity will be more pronounced when the $\mathrm{CEO}$ is a familial manager rather than a professional manager.

Hypothesis 2: The relationship between family involvement in middle management and family firms' labor productivity will be moderated by the CEO's family membership such that the negative relationship will be stronger when the CEO is a family member. 


\section{Organizational Contingency: Firm Size}

Firm size is an important contingency factor that interplays with family involvement in middle management in affecting family firms' labor productivity. First, compared with small firms, large firms are more dependent on professional management than on family management. Larger firms are commonly associated with more-complex administrative tasks (Zhang \& Ma, 2008). As firm size increases, it is likely that middle managers' span of control tends to increase (Urwick, 1922). In this sense, larger family firms have to rely more on outside professional managers because the number of family members who are willing to manage and are capable of doing so tend to be limited (Chua et al., 2003). Thus, when family firms continue to rely on relatively incompetent family members to serve as middle managers even though increased firm size may require more external talents, then a high degree of family involvement in middle management may jeopardize firms' performance to a greater extent.

In addition, a key difference between small and large firms is the level of regularity and normality (Chu, 2011; Li, Zhou, \& Zajac, 2009). Small firms are generally more flexible in management and implement fewer norms and regulations, so managers in small firms are endowed with greater discretion over managerial decisions. In contrast, large firms are more likely to establish formal protocols and standard operating procedures to regulate employees' behaviors (Kimberly, 1976). For example, Chu (2011) suggests that the association between family ownership and firm performance is more significant in small- and medium-sized firms than in large firms. This means that managers in large firms are commonly granted relatively less discretion over managerial decisions. We therefore anticipate an interaction between family involvement in middle management and firm size. Specifically, employing family members may be seen as more legitimate in family firms of small size as in these firm owners have more discretion or even absolute control over managerial issues. Thus, employing family members as middle managers is less likely to trigger nonfamily employees' perception of injustice and hence their negative consequential reactions. However, in large firms, more-comprehensive norms and procedures are often in place to regulate employees' behavior and standardize management practices. In these organizations, people act according to formal regulations, and the pursuit of procedural justice may become a salient concern for employees. Therefore, family involvement in middle management in larger firms is more likely to invoke the perception of injustice among nonfamily employees and negatively affect labor productivity.

Taken together, we expect that family involvement in middle management diminishes family firms' labor productivity to a larger extent among firms of greater size. 
Hypothesis 3: The relationship between family involvement in middle management and family firms' labor productivity will be moderated by firm size such that the negative relationship is stronger in larger firms.

\section{Regional Contingency: Labor Mobility}

Local labor market conditions play a key role in shaping people's interpretations and reactions to their current working situations (Mitchell, Holtom, Lee, Sablynski, \& Erez, 2001). Labor mobility reflects the ease with which people are able to move to different organizations (Gerhart, 1990). We argue that when a region's labor mobility is low, adverse selection will be more likely to occur. In a region with low labor mobility, it may be difficult for family members to find a job as good as a middle manager in a family firm. In this case family members will make more efforts to get into the family business, and because of kinship family owners are more likely to hire these family members even when they are not sufficiently competent. In addition, when family middle managers make mistakes or perform poorly they are less likely to be laid off because there are fewer job opportunities outside the firm. That is, when family firms are located in regions with low labor mobility, the agency problem is amplified due to family owners' altruism in taking care of their family members and maintaining their job security.

People may also attach more importance to internal career development when regional labor mobility is low. Due to insufficient job opportunities outside, internal promotion becomes the key means for low-level employees to achieve career development (Gerhart, 1990). In other words, employees are more likely to implement a long-term career plan in the current firm instead of searching for alternatives in the job market. Under such circumstance, employees may pay particular attention to information related to internal career development and any signal that reveals unfair procedure of appointment or promotion decisions may invoke stronger negative reactions from employees. Traditional models of turnover (e.g., Hom \& Griffeth, 1994) predict that employees tend to exit the organization when they have low job satisfaction. However, they may get stuck in their current position if job market conditions are not favorable, e.g., low labor mobility (Gerhart, 1990). In this case, employees may act passively and even engage in counterproductive workplace behavior in order to achieve a balanced exchange with the organization (Cropanzano \& Mitchell, 2005). Therefore, in regions with lower labor mobility, family involvement in middle management is more likely to induce employees' perception of injustice as well as their stronger negative response to unfair treatment caused by family management.

Taken together, we expect that family involvement in middle management will have a stronger negative effect on labor productivity in family firms located in regions with lower labor mobility than those located in regions with higher labor mobility. 
Hypothesis 4: The relationship between family involvement in middle management and family firms' labor productivity will be moderated by the regional labor mobility such that the negative relationship is stronger when the labor mobility is lower.

\section{METHODS}

\section{Data and Sample}

Data used in this study were drawn from the ninth survey of Chinese privately owned enterprises conducted by the Privately Owned Enterprises Research Project Team (POERPT) in 2010. This survey is conducted every two years nationwide. Its purpose is to detect problems in the development of the private economy and provide policy recommendations to authorities. The 2010 survey contained information about family firms, including business structure, corporate governance, succession, labor protection, and other basic statistical facts. Using a multistage stratified sampling procedure, the research team first generated a national representative sample of POEs and then sent questionnaires to the entrepreneurs of the POEs included in the sample. A POE's financial manager was asked to provide basic information about the firm, and firm owners reported other data such as family membership of department administrators and the source of the CEO.

Following previous research on family businesses, we chose observations in which families maintain over 50 percent of the firms' ownership as our sample (He, Song, Zhu, \& Li, 2014). After eliminating responses with obvious mistakes or missing values, we ended up with a valid sample of 1,284 private family firms. These firms were distributed throughout nineteen industries, among which 45.25 percent belonged to the manufacturing industry. Regarding business structure, 9.11 percent of the enterprises were sole proprietorship, 6.54 percent were partnership, 72.20 percent were limited liability companies (LLC), and 12.15 percent were joint stock companies (JSG). The average firm age was 9 years.

\section{Variables}

Labor productivity. Labor productivity is one of the most suitable indicators of workforce performance (Delery \& Shaw, 2001). In this study, we followed convention in using the logarithm of sales per employee to measure labor productivity (Datta, Wright, \& Guthrie, 2005; Huselid, 1995; Iverson \& Zatzick, 2011). Specifically, we divided a firm's sales revenue in 2010 by the total number of employees in the firm (Huselid, 1995). We used the logarithm forms of this index as the dependent variable to correct for the skewed distribution.

Family involvement in middle management. Our independent variable, family management, was measured by the percentage of department managers who were 
related to the entrepreneur's family (Sciascia \& Mazzola, 2008). In the survey questionnaire, entrepreneurs were asked to indicate their relationship with the seven department administrators respectively. The relationships were grouped into five categories: (1) spouses, parents, or children, (2) other lineal relatives, (3) in-laws, (4) friends or schoolmates, (5) no special relationship. We regarded a department manager as a family member if the entrepreneur chose 1, 2 or 3; otherwise the manager was labeled as a nonfamily employee. We then calculated the percentage of family members in middle-level management by dividing the number of familial managers by the total number of department managers.

Familial CEO. To capture whether the supervisor-subordinate relationship between CEOs and department managers overlapped with family ties we created a dummy variable. The value one indicated that the CEO was a family member, and zero otherwise.

Firm size. Consistent with previous research (Li et al., 2009; Maury, 2006), we used the logarithm of total assets in 2010 as a measure of firm size.

Labor mobility. This regional indicator was not measured in the questionnaire. Instead, we used a third-party source data National Economic Research Institute's (NERI) Index of Chinese Provinces to measure regional labor mobility (Fan, Wang, \& Zhu, 2011). We chose provincial labor mobility from the many subindicators of the maturity of the elements market. Consistent with the extant literature (Li \& Zhang, 2010), we averaged the labor mobility of the previous three years (2007-2009) and used it to measure the level of labor mobility in a province.

Control variables. We incorporated several control variables in our study. First, we controlled for industry. Specifically, we generated eighteen dummy variables based on NBSC (National Bureau of Statistics of China) classifications. At the firm level, we controlled for business structure and firm age. We recoded the categorical business structure variable into three dummy variables indicating whether a firm is a partnership, a limited liability company, or a joint stock company. Firm age refers to the number of years that the firm had operated in China by the end of 2010. In addition, since unions may have an impact on labor productivity (Datta et al., 2005), we added a dummy variable to control for the existence of unions. Lastly, we controlled for the maturity of a firm's governance structure. We coded governance structure as one if a family firm had a board of directors, shareholders' meetings, and a board of supervisors, and otherwise coded zero (Liang, Chen, \& Ge, 2010). We expected that labor productivity would be higher when family firms had a more-mature governance structure. 


\section{RESULTS}

Family management at the middle level is by nature related to nepotism (i.e., recruiting family members). Prior studies have not provided any specific statistics about this phenomenon. We therefore decided to first conduct a descriptive analysis before the hypothesis testing to determine whether appointing family members as middle managers is a widely adopted practice in family firms. In our sample (1,284 privately owned family firms), 57.09 percent of family firms had as least one family member as a department manager. Table 1 presents the frequency of using family or nonfamily managers for each type of department among the sample. For all types of department, a certain percentage (at least 9.89 percent) of family firms had at least one family member as department manager. It is interesting to observe the difference among the seven departments. Specifically, family firms are most likely to have family members supervising the financial department (33.02 percent) and purchasing department (36.52 percent), but least likely to appoint family members as the R\&D department manager (9.89 percent). Since the financial department and purchasing department deal with a firm's cash flow, family owners may consider a family member more trustworthy in these positions compared to nonfamily members, whereas, the $\mathrm{R} \& \mathrm{D}$ department requires expertise that family members may lack. Family firms are thus more likely to recruit nonfamily professionals as the $\mathrm{R} \& \mathrm{D}$ manager.

Table 2 presents the correlation matrix and descriptive statistics for the major variables. Family involvement in middle management was negatively associated with labor productivity $(\mathrm{r}=-0.13, \mathrm{p}<0.001)$, providing basic evidence supporting $\mathrm{H} 1$.

We used ordinary least square (OLS) regression to test our hypotheses. Because the firms we studied were nested in provinces, we used clustered robust standard errors to estimate the effects of the covariates. Table 3 presents the results of the main effect and the three moderation effects. We first added all the control variables in Model 1. The results showed that a region's labor mobility was positively related to labor productivity of family firms, and larger family firms had higher labor productivity. $\mathrm{Hl}$ predicts that family involvement in middle management will be negatively associated with labor productivity. To test $\mathrm{H} 1$, we added the independent variable in Model 2. The results showed that family involvement in middle management was negatively related to labor productivity $(\beta=-0.06, \mathrm{p}=$ 0.028 ). It indicated that with family involvement in middle management increasing by one standard deviation, labor productivity would decrease by 0.02 (equivalent to loss of 10200 yuan per employee). H1 was therefore supported. Comparing Model 2 to Model 1 , the $\Delta \mathrm{R} 2$ was 0.01 , indicating that family involvement in middle management explained 1 percent of the variance of labor productivity. In our sample a 1 percent change of productivity means an approximately 1.98 million yuan increment or decrement of sales on average. This indicates that although the additional variance explained by family involvement in management is relatively 
Table 1. Summary on the family owners' relationships with middle-level managers in our sample

\begin{tabular}{|c|c|c|c|c|c|c|c|}
\hline Relationship with owner & Financial & Purchasing & Sales & Human Resources & $R E D$ & Manufacturing & Administration \\
\hline Family managers & $424(33.02 \%)$ & $469(36.52 \%)$ & $314(24.45 \%)$ & $226(17.60 \%)$ & $127(9.89 \%)$ & $210(16.36 \%)$ & $211(16.43 \%)$ \\
\hline Spouses, parents, or children & 255 & 150 & 112 & 98 & 49 & 51 & 80 \\
\hline Other linear relatives & 140 & 249 & 153 & 96 & 61 & 120 & 105 \\
\hline In-laws & 29 & 70 & 49 & 32 & 17 & 39 & 26 \\
\hline Non-family managers & $860(66.98 \%)$ & $815(63.48 \%)$ & $970(75.55 \%)$ & $1058(82.40 \%)$ & $1157(90.11 \%)$ & $1074(83.64 \%)$ & $1073(83.57 \%)$ \\
\hline Friends or schoolmates & 63 & 81 & 97 & 84 & 86 & 88 & 78 \\
\hline No special relationship & 797 & 734 & 873 & 974 & 1071 & 986 & 995 \\
\hline
\end{tabular}

Note: $\mathrm{n}=1284$. 
Table 2. Correlation matrix and descriptive statistics

\begin{tabular}{|c|c|c|c|c|c|c|c|c|c|c|c|c|c|}
\hline \multicolumn{2}{|c|}{ Variable } & \multirow{2}{*}{$\frac{\text { Mean }}{0.07}$} & \multirow{2}{*}{$\begin{array}{l}\text { S.D. } \\
0.25\end{array}$} & \multirow[t]{2}{*}{1} & \multirow[t]{2}{*}{2} & \multirow[t]{2}{*}{3} & \multirow[t]{2}{*}{4} & \multirow[t]{2}{*}{5} & \multirow[t]{2}{*}{6} & \multirow[t]{2}{*}{7} & \multirow[t]{2}{*}{8} & \multirow[t]{2}{*}{9} & \multirow[t]{2}{*}{10} \\
\hline 1 & Partnership $(1=$ Yes, $0=$ No) & & & & & & & & & & & & \\
\hline 2 & LLG $(1=$ Yes, $0=\mathrm{No})$ & 0.72 & 0.45 & $-0.43^{* * *}$ & & & & & & & & & \\
\hline 3 & JSG $(1=$ Yes, $0=$ No $)$ & 0.12 & 0.33 & $-0.10^{* * *}$ & $-0.60^{* * *}$ & & & & & & & & \\
\hline 4 & Firm age & 9.00 & 4.47 & 0.01 & -0.04 & 0.03 & & & & & & & \\
\hline 5 & Firm size & 6.53 & 1.99 & $-0.10^{* * *}$ & 0.01 & $0.15^{* * *}$ & $0.25^{* * *}$ & & & & & & \\
\hline 6 & Unionization & 0.57 & 0.50 & 0.02 & $-0.05^{*}$ & 0.02 & $0.25^{* * *}$ & $0.38^{* * *}$ & & & & & \\
\hline 7 & Governance structure & 0.21 & 0.40 & $-0.06^{* *}$ & -0.01 & $0.16^{* * *}$ & 0.03 & $0.25^{* * *}$ & $0.21^{* * *}$ & & & & \\
\hline 8 & Familial CEO & 0.90 & 0.30 & 0.02 & 0.04 & $-0.07^{* *}$ & -0.01 & $-0.14^{* * *}$ & -0.02 & $-0.07^{* *}$ & & & \\
\hline 9 & Labor mobility & 6.68 & 2.91 & $0.05^{*}$ & $-0.06^{* *}$ & $0.07^{* *}$ & $0.05^{*}$ & $0.08^{* *}$ & $0.14^{* * *}$ & $0.07^{* *}$ & -0.01 & & \\
\hline 10 & $\begin{array}{l}\text { Family involvement in middle } \\
\text { management }\end{array}$ & 0.22 & 0.28 & $-0.05^{*}$ & 0.03 & $-0.07^{* *}$ & -0.03 & $-0.18^{* * *}$ & $-0.13^{* * *}$ & $-0.10^{* * *}$ & $0.12^{* * *}$ & 0.01 & \\
\hline 11 & Labor productivity & 3.04 & 1.28 & -0.02 & 0.03 & 0.03 & $0.10^{* * *}$ & $0.38^{* * *}$ & $0.09^{* *}$ & $0.07 * *$ & -0.03 & $0.09 * *$ & $-0.13^{* * *}$ \\
\hline
\end{tabular}

Notes: $\mathrm{n}=1,284 ;{ }^{*} \mathrm{p}<0.1,{ }^{* *} \mathrm{p}<0.05,{ }^{* * *} \mathrm{p}<0.01$. 
Table 3. OLS models predicting the main effect of family involvement in middle management and the moderating effects

\begin{tabular}{|c|c|c|c|c|c|c|c|c|c|c|c|c|c|c|c|c|c|c|}
\hline \multirow[t]{2}{*}{ Variables } & \multicolumn{3}{|c|}{ Model 1} & \multicolumn{3}{|c|}{ Model 2} & \multicolumn{3}{|c|}{ Model 3} & \multicolumn{3}{|c|}{ Model 4} & \multicolumn{3}{|c|}{ Model 5} & \multicolumn{3}{|c|}{ Model 6} \\
\hline & $\beta$ & se & $\mathrm{p}$ & $\beta$ & se & $\mathrm{p}$ & $\beta$ & se & $\mathrm{p}$ & $\beta$ & se & $\mathrm{p}$ & $\beta$ & se & $\mathrm{p}$ & $\beta$ & se & $\mathrm{p}$ \\
\hline $\begin{array}{l}\text { Family involvement in middle } \\
\text { management }\end{array}$ & - & - & - & -0.06 & 0.13 & 0.028 & -0.05 & 0.13 & 0.070 & -0.07 & 0.13 & 0.013 & -0.05 & 0.13 & 0.064 & -0.05 & 0.14 & 0.086 \\
\hline $\begin{array}{l}\text { Familial CEO } \times \text { Family } \\
\text { involvement in middle } \\
\text { management }\end{array}$ & - & - & - & - & - & - & -0.03 & 0.63 & 0.311 & - & - & - & - & - & - & -0.04 & 0.66 & 0.270 \\
\hline $\begin{array}{l}\text { Firm size } \times \text { Family } \\
\text { involvement in middle } \\
\text { management }\end{array}$ & - & - & - & - & - & - & - & - & - & -0.07 & 0.06 & 0.015 & - & - & - & -0.08 & 0.06 & 0.003 \\
\hline $\begin{array}{l}\text { Labor mobility } \times \text { Family } \\
\text { involvement in middle } \\
\text { management }\end{array}$ & - & - & - & - & - & - & - & - & - & - & - & - & 0.07 & 0.04 & 0.013 & 0.08 & 0.04 & 0.004 \\
\hline Familial CEO & 0.01 & 0.11 & 0.590 & 0.02 & 0.12 & 0.461 & 0.01 & 0.13 & 0.764 & 0.03 & 0.12 & 0.362 & 0.02 & 0.12 & 0.495 & 0.01 & 0.13 & 0.695 \\
\hline Firm size & 0.41 & 0.02 & 0.000 & 0.40 & 0.02 & 0.000 & 0.40 & 0.02 & 0.000 & 0.40 & 0.02 & 0.000 & 0.39 & 0.02 & 0.000 & 0.40 & 0.02 & 0.000 \\
\hline Labor mobility & 0.08 & 0.01 & 0.002 & 0.09 & 0.01 & 0.002 & 0.09 & 0.01 & 0.002 & 0.09 & 0.01 & 0.001 & 0.08 & 0.01 & 0.006 & 0.08 & 0.01 & 0.004 \\
\hline Partnership & 0.02 & 0.16 & 0.460 & 0.02 & 0.16 & 0.609 & 0.02 & 0.16 & 0.608 & 0.02 & 0.16 & 0.607 & 0.02 & 0.16 & 0.595 & 0.02 & 0.16 & 0.590 \\
\hline LLC & 0.03 & 0.11 & 0.488 & 0.02 & 0.11 & 0.589 & 0.02 & 0.11 & 0.593 & 0.02 & 0.11 & 0.598 & 0.02 & 0.11 & 0.568 & 0.02 & 0.11 & 0.579 \\
\hline JSC & -0.02 & 0.14 & 0.636 & -0.02 & 0.14 & 0.514 & -0.02 & 0.14 & 0.496 & -0.02 & 0.14 & 0.526 & -0.02 & 0.14 & 0.534 & -0.02 & 0.14 & 0.532 \\
\hline Firm age & 0.02 & 0.01 & 0.513 & 0.02 & 0.01 & 0.494 & 0.02 & 0.01 & 0.491 & 0.02 & 0.01 & 0.453 & 0.02 & 0.01 & 0.510 & 0.02 & 0.01 & 0.458 \\
\hline Unionization & -0.04 & 0.08 & 0.169 & -0.05 & 0.07 & 0.110 & -0.05 & 0.07 & 0.104 & -0.05 & 0.07 & 0.103 & -0.04 & 0.08 & 0.132 & -0.05 & 0.07 & 0.118 \\
\hline Governance structure & -0.01 & 0.09 & 0.780 & -0.01 & 0.09 & 0.703 & -0.01 & 0.09 & 0.685 & -0.02 & 0.09 & 0.572 & -0.01 & 0.09 & 0.705 & -0.02 & 0.09 & 0.528 \\
\hline Industry controls & included & & & included & & & included & & & included & & & included & & & included & & \\
\hline Observations & 1284 & & & 1284 & & & 1284 & & & 1284 & & & 1284 & & & 1284 & & \\
\hline R2 & 0.21 & & & 0.22 & & & 0.22 & & & 0.22 & & & 0.22 & & & 0.23 & & \\
\hline $\mathrm{F}$ & $54.88^{* * *}$ & & & $22.87^{* * *}$ & & & $21.10^{* * *}$ & & & $54.77^{* * *}$ & & & $119.02^{* * *}$ & & & $52.14^{* * *}$ & & \\
\hline
\end{tabular}




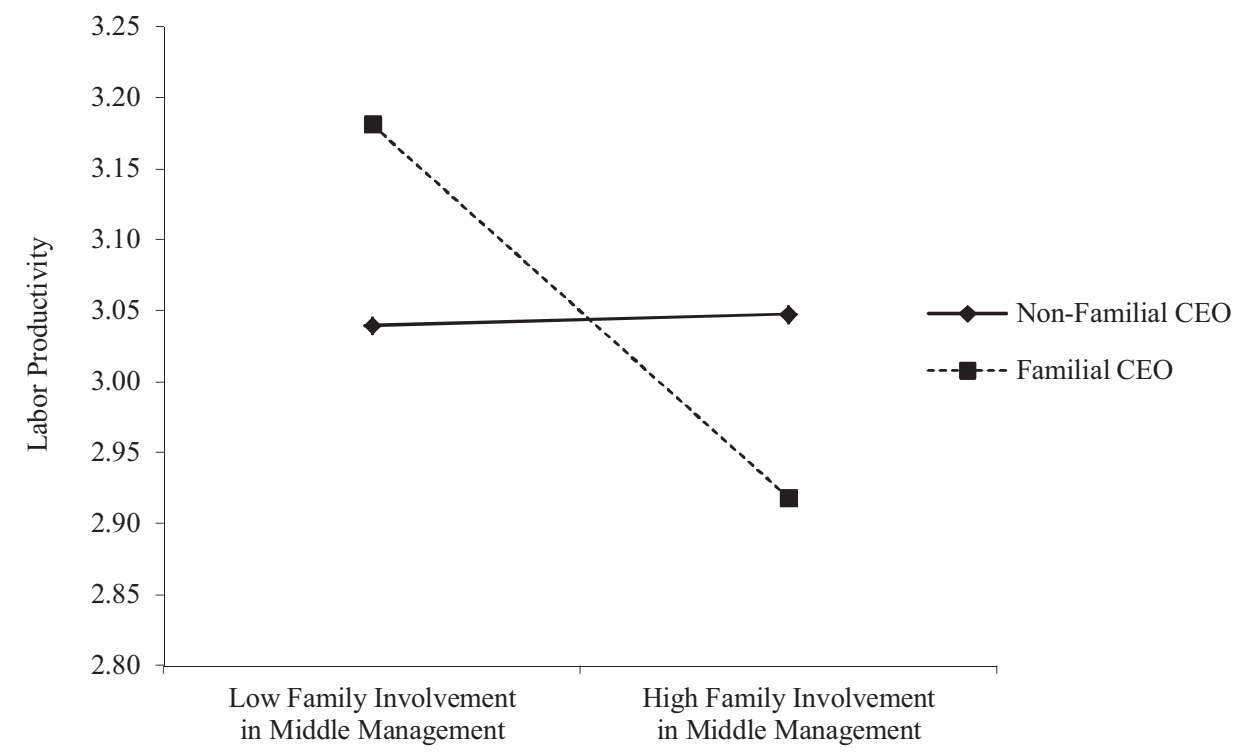

Figure 1. The moderation effect of familial CEO on the relationship between family involvement in middle management and labor productivity.

small, this small variance will still have a dramatic effect on these off-the-list family firms.

$\mathrm{H} 2$ predicts that the negative relationship between family involvement in middle management and labor productivity will be stronger when the CEO is a family member instead of a professional manager. As shown in Model 3, the interaction term of family involvement in middle management and familial CEO was not significantly related to labor productivity $(\beta=-0.03, \mathrm{p}=0.311)$. Thus, H2 was not supported. However, considering that familial CEO is a dummy variable, we further split the full sample and tested the relationship between family involvement in middle management and labor productivity respectively in two subsamples. The results showed that when family members occupied the position of CEO $(\mathrm{n}=1151)$, family involvement in middle management was negatively related to labor productivity $(\beta=-0.11, \mathrm{p}<0.001)$, whereas when a professional manager was the $\operatorname{CEO}(\mathrm{n}=133$ ), family involvement in middle management was not related to labor productivity $(\beta=-0.04, \mathrm{p}=0.761)$ (illustrated in Figure 1). It indicated that when the $\mathrm{CEO}$ was a professional manager, the CEO would monitor family middle managers more effectively and thus the possible negative consequence caused by family involvement in middle management would be avoided. Notwithstanding that the moderation hypothesis was not supported, in doing so, we found differential effects of family involvement in middle management on labor productivity between firms with a familial CEO and firms with a professional CEO.

$\mathrm{H} 3$ predicts that the negative relationship between family involvement in middle management and labor productivity will be stronger for larger family firms. 


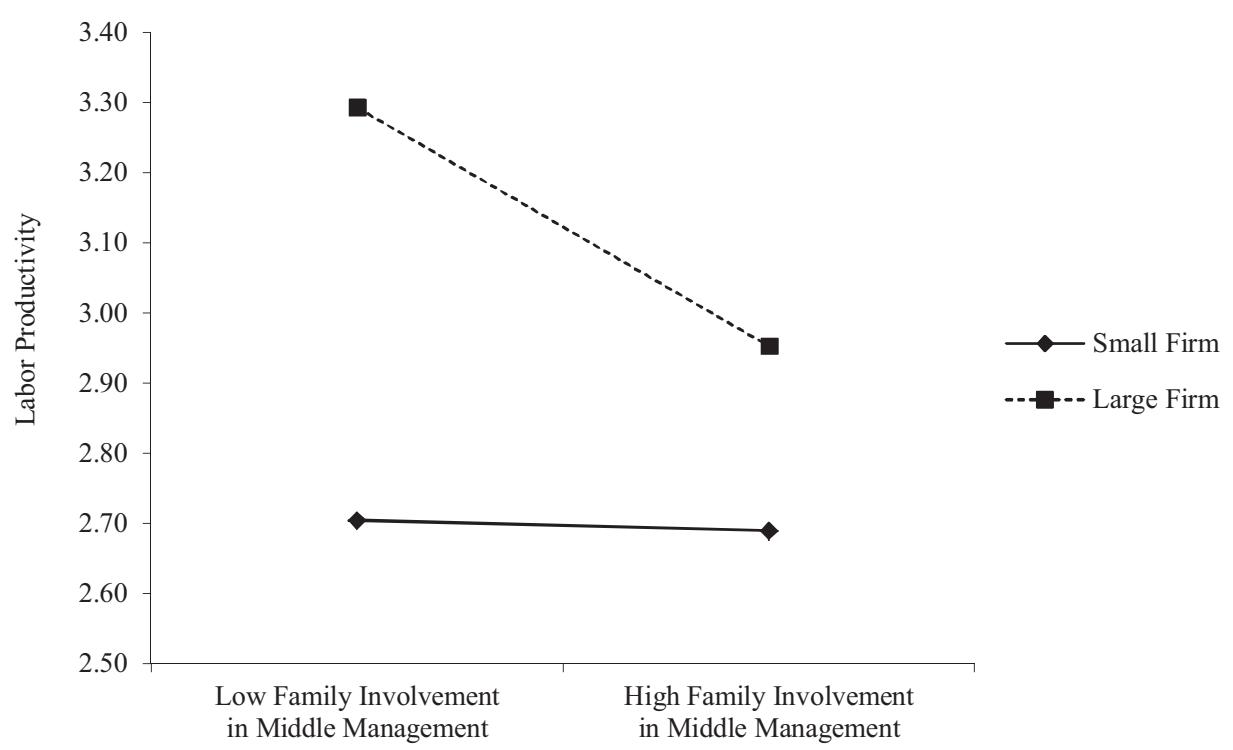

Figure 2. The moderation effect of firm size on the relationship between family involvement in middle management and labor productivity.

As shown in Model 4, the interaction term of family involvement in middle management and firm size was negatively related to labor productivity $(\beta=$ $-0.07, \mathrm{p}=0.015)$, indicating that firm size strengthens the relationship between family involvement in middle management and labor productivity. Furthermore, for large family firms (one SD above mean; $\mathrm{n}=357$ ) family involvement in middle management was negatively related to labor productivity $(\beta=-0.13, \mathrm{p}=$ 0.006), whereas for small family firms (one SD below mean; $\mathrm{n}=389$ ) there was no significant relationship between family involvement in middle management and labor productivity $(\beta=0.02, \mathrm{p}=0.731)$ (illustrated in Figure 2). H3 was therefore supported. The nonsignificant relationship found in small family firms shows that when the firm size is small, the practice of appointing family members as middle managers will not hurt the overall workforce efficiency of the firm. Our explanation is that in small family firms, family middle managers may be capable for administrative tasks, and meanwhile family involvement may be viewed as legitimate by nonfamily employees.

$\mathrm{H} 4$ predicts that the negative relationship between family involvement in middle management and labor productivity will be stronger when regional labor mobility is lower. As shown in Model 5, the interaction term of family involvement in management and labor mobility was positively related to labor productivity $(\beta=$ 0.07, $\mathrm{p}=0.013$ ), indicating that regional labor mobility weakens the relationship between family involvement in middle management and labor productivity. Furthermore, for family firms located in regions with high labor mobility (one SD above mean; $\mathrm{n}=202$ ) there was no relationship between family involvement in middle management and labor productivity $(\beta=0.10, \mathrm{p}=0.139)$, whereas for 


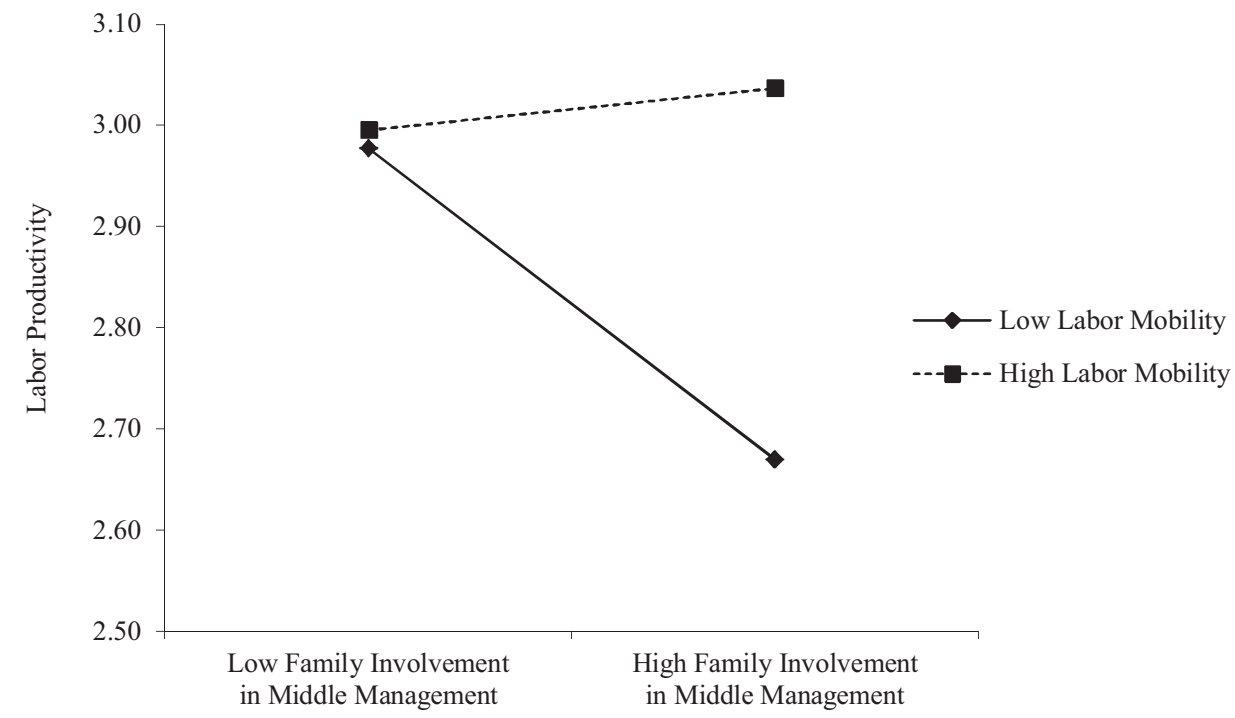

Figure 3. The moderation effect of labor mobility on the relationship between family involvement in middle management and labor productivity.

family firms located in regions with low labor mobility (one SD below mean; $\mathrm{n}=$ 256) family involvement in middle management was negatively related to labor productivity $(\beta=-0.26, \mathrm{p}<0.001)$ (illustrated in Figure 3$)$. H4 was therefore supported. It is worth noting that the detrimental effect of family involvement in middle management does not exist for family firms located in regions with high labor mobility because on one hand, family owners will be less likely to hire incompetent family members as there are many other job opportunities outside the family firm, and on the other hand, nonfamily employees will react less negatively to unfair treatment as they can exit the current firm and find an alternative job.

In Model 6 we added the three interaction terms. The results showed that the interaction of family involvement in middle management and firm size was negatively related to productivity $(\beta=-0.08, \mathrm{p}=0.003)$, and the interaction of family involvement in middle management and labor mobility was positively related to labor productivity $(\beta=0.08, \mathrm{p}=0.004)$. This provides further evidence for $\mathrm{H} 3$ and $\mathrm{H} 4$ in the full model.

\section{Robustness Check}

Although our research focus is on family involvement in middle management, it is valuable to explore whether its effect is differentiated from family involvement in top management. Since our sample was comprised of private family firms, many of these firms' governance structures were relatively underdeveloped. Among our final sample, 53.50 percent established a board of directors. Using this subsample ( $\mathrm{n}=683$ ), we controlled for family involvement in top management (i.e., measured 
as percentage of family members in the board of directors), and reran the main effect model. The results showed that family involvement in top management had no significant relationship with labor productivity $(\beta=0.06, \mathrm{p}=0.113)$, while family involvement in middle management still had a significantly negative relationship with labor productivity $(\beta=-0.11, \mathrm{p}=0.003)$. We are therefore confident that family involvement in middle management will negatively impact family firms' labor productivity despite family involvement in top management.

Second, since family firms are nested in different provinces, labor mobility is a province-level variable. As such, the moderating effect of labor mobility on the relationship between family involvement in middle management and labor productivity is a cross-level interaction. We therefore constructed a hierarchical linear model to test this interaction effect. Specifically, we chose labor mobility as the group-level variable. We followed Hofmann and Gavin's (1998) method and centered the individual-level predictor using the grand mean. This approach made it easier to interpret the results as well as control for individual-level effects when testing the incremental effects of group-level variables. The results of the hierarchical regression showed that labor mobility weakened the negative relationship between family involvement in middle management and labor productivity $(b=0.06, p=0.024)$. This finding was consistent with previous results regarding $\mathrm{H} 4$.

Furthermore, we generated a dummy variable to indicate a region's labor mobility. Business competition is stronger in highly developed regions than it is in less-developed regions. Correspondingly, the labor market is also more mature. In China, the division of coastal provinces and inland provinces is a typical demarcation line of economic development. We therefore predicted that the negative relationship between family involvement in middle management and labor productivity would be stronger in family firms located in inland regions than those located in coastal regions. We coded inland regions as a dummy variable. Inland regions were coded as zero if the location of a family firm was in Liaoning, Beijing, Tianjin, Shandong, Jiangsu, Shanghai, Zhejiang, Fujian, Guangzhou, or Hainan, and one otherwise (Li et al., 2009). In the subsample of inland firms $(\mathrm{n}=640)$, the regression result showed that family involvement in middle management was negatively related to labor productivity $(\beta=-0.10, \mathrm{p}=$ $0.011)$. However, in the subsample of coastal firms $(n=644)$, family involvement in middle management had no significant relationship with labor productivity $(\beta=$ $-0.002, \mathrm{p}=0.955)$. This result was consistent with our prediction, providing further evidence for the region effect.

\section{DISGUSSION}

This research expands studies on the relationship between family involvement and firm performance by directing scholarly attention from upper-echelon to middle management. We borrowed insights from agency theory and the organizational 
justice perspective and theorized that family involvement in middle management, indicated as percentage of family members among middle managers, would incur alternative forms of agency costs and perceptions of injustice among employees and would thus adversely affect family firms' labor productivity. Moreover, we further embedded this relationship into organizational and regional economic contexts and examined how firms' leaders, organizational characteristics, and the features of the local labor market could exacerbate or alleviate the negative impact of family involvement in middle management on labor productivity. We found that the negative effect of family involvement in middle management existed only when the $\mathrm{CEO}$ was a family member, or when the size of the firm was large, or when the firm was located in a region with low labor mobility.

\section{Theoretical Contributions}

The present study contributes to the existing literature in the following aspects. First, our study draws attention to the role of family involvement in middle management. To the best of our knowledge, this study is the first to focus on family managers at the middle level and provide empirical evidence on its role on family firms' labor productivity. Family involvement is one of the most salient characteristics of family businesses. Researchers have devoted much effort to investigating the effects of family involvement in ownership, control, and management on firm outcomes. Although these efforts have yielded rich evidence that highlights the importance of family involvement, most prior studies focus on positions at the strategic apex of organizations such as family owners, family board members, and family CEO. Family members in these positions play a critical role because they have great influence on family firms' strategic decisions, which determine the sustainment as well as the development of a family business. However, compared with top-level 'big names' at the strategic apex, middle managers usually play a more-important role in carrying out the policies and decisions made by corporate leaders (Floyd \& Wooldridge, 1994, 1997). They are mainly responsible for internal daily operations and control, and the composition of the middle management team has an immediate and direct impact on the efficiency of family firms. Adopting the perspectives of agency theory and organizational justice, this study reveals that family involvement in middle management is detrimental to family firms' labor productivity.

Second, we incorporated the organizational justice perspective into our theorizing, providing a micro foundation for the effect of family involvement. Most previous studies on family involvement do not explicitly consider the role of nonfamily employees. In fact, family involvement may influence firm performance by affecting nonfamily members' motivation, attitude, and behavior. This is particularly important when we look at family middle managers because they are responsible for supervising and motivating frontline employees. By integrating the organizational justice perspective into this study, we offer a new 
angle for understanding the phenomenon of family involvement. In this way, the study also contributes to organizational justice by extending a micro theory into a more macro phenomenon, which is a meaningful attempt at micro-macro integration.

Third, we explore the boundary conditions of familial CEO, firm size, and regional labor mobility. Our study shifts the focus from the higher level to the middle level, proposing three important contingencies for understanding how this internal practice at the middle level interplay with other factors, which can even be factors outside of the organization, to jointly affect the performance of the family business. We argue that these contingencies affect the quality of middlelevel managers' social interactions with other members within the organization and hence affect the family firms' labor productivity. In doing so, we paid particular attention to the role of middle managers facing different social actors in the organization. Habbershon, Williams, and MacMillan (2003) propose a unified systems model of family business to highlight the importance of social interactions among different members in the family organization. In line with this perspective, we found that such negative impact existed only when the CEO has a familial identity, the firm is large in size, or the external labor market has low mobility. These findings reveal the situations in which the negative consequence of family involvement in middle management is more pronounced, and they extend our understanding of the interactions among different shareholders related to family businesses.

Fourth, we adopted a multilevel approach to exploring the boundary conditions of the main effect in this research. The cross-level interaction effect between family involvement in middle management and a region's labor mobility clearly shows how family businesses, just like other economic organizations, are nested in broad social institutions. The association between the firm and the region implies that this internal practice may generate distinct effects on labor productivity given the different situations of the external labor market. Although a family business has a unique way of dealing with external institutional constraints and focus on its noneconomic goals (e.g., Berrone, Cruz, \& Gomez-Mejia, 2012), our study implies that regional influence still penetrates into the family business. What is more, adopting a multilevel approach does not simply refer to our investigation of the cross-level interactions, but also means efforts in bridging perspectives at different levels to address the same research question.

\section{Limitations and Future Research Directions}

This study inevitably has several limitations. First, we cannot safely draw a casual inference from our findings based on the cross-sectional data used. One major problem of using cross-sectional data is reversed causality, which means that reduced labor productivity may lead to a higher level of family involvement in middle management but not the vice versa. However, we suggest that this is 
unlikely. First, when the financial manager in each firm reported their performance information as a 'snapshot', middle-level managers had usually been working in their positions over a period of time. This reasonable inference of the reality suggests that it is more likely that our independent variable precedes the dependent variable in time. Second, a rationale to explain the reversed causality is that family businesses hire family members in order to cut costs or improve revenue in response to reduced labor productivity. However, previous research has implied that hiring family members is commonly not an attempt to achieve economic objectives (Cennamo et al., 2012). Thus, in spite of the challenges from using cross-sectional data, we suggest that this secondhand large dataset is the best we can currently utilize to answer the research question, and it is more likely that our proposed relationship instead of the reversed causality remains.

Second, we tested our hypotheses only based on a sample of Chinese private family firms, and scholars could examine the generalizability of our findings in other emerging markets such as the BRIC (Brazil, Russia, India, and China) countries or SIVETS (Colombia, Indonesia, Vietnam, Egypt, Turkey, and South Africa). Although the theoretical pillars that support our arguments are relatively context free, it is possible that family involvement in these countries may demonstrate different characteristics, so its effect on labor productivity varies. In addition, we only focused on private family firms whose governance structures are relatively underdeveloped and in which nepotism is more likely to be a severe management problem. However, in public family firms, where the firm's governance structure is well developed, the possible negative influences of family involvement in middle management may be weakened.

Third, we must acknowledge the limitation that we did not directly measure employees' perception of injustice although we used it as one of the major underlying arguments in the study. Without the measure we cannot completely rule out alternative explanations of the negative effect we found, although empirical evidence of the three interactions effects are consistent with the injustice reasoning. This limitation is due to the use of the secondhand data, because it does not provide any justice-relevant information that we can use to test the underlying mechanism. We strongly encourage scholars who are interested in family management to include the measure of justice perception in future research to further examine this important argument.

Fourth, future research could explore how family members working in different functions may bring about different impacts on firm performance. For example, although approximately one-third of the private family firms tend to hire a family member as the manager of their financial department, it may not be a wise decision because the financial department requires high expertise and the financial manager ought to be independent and objective in dealing with financial issues. Due to the existence of family ties the financial manager may be biased in his/her decision making, which may endanger a firm's long term economic performance. 


\section{NOTE}

This research was partially supported by a grant from the National Natural Science Foundation of China (\#71632002).

\section{REFERENGES}

Anderson, R. C., \& Reeb, D. M. 2003. Founding-family ownership and firm performance: Evidence from the S\&P 500. The Journal of Finance, 58(3): 1301-1327.

Anderson, R. C., \& Reeb, D. M. 2004. Board composition: Balancing family influence in S\&P 500 firms. Administrative Science Quarterly, 49(2): 209-237.

Arnold, D. J., \& Quelch, J. A. 1998. New strategies in emerging markets. MIT Sloan Management Review, 40(1): 7-20.

Barnett, T., \& Kellermanns, F. W. 2006. Are we family and are we treated as family? Nonfamily employees' perception of justice in the family firm. Entrepreneurship Theory and Practice, 30(6): 837-854.

Barontini, R., \& Caprio, L. 2006. The effect of family control on firm value and performance: Evidence from continental Europe. European Financial Management, 12(5): 689-723.

Bartlett, C. A., \& Ghoshal, S. 1993. Beyond the M-form: Toward a managerial theory of the firm. Strategic Management Journal, 14(52): 23-46.

Bergstrom, T. C. 1989. A fresh look at the rotten kid theorem and other household mysteries. Journal of Political Economy, 97(5): 1138-1159.

Berrone, P., Cruz, G., \& Gomez-Mejia, L. R. 2012. Socioemotional wealth in family firms: Theoretical dimensions, assessment approaches, and agenda for future research. Family Business Revieze, 25(3): 258-279.

Birley, S. 2001. Owner-manager attitudes to family and business issues: A 16 country study. Entrepreneurship: Theory and Practice, 26(2): 63-76.

Bourgeois, L. J. 1985. Strategic goals, perceived uncertainty, and economic performance in volatile environments. Academy of Management Journal, 28(3): 548-573.

Bruce, N., \& Waldman, M. 1990. The rotten kid theorem meets the Samaritan's dilemma. The Quarterly Journal of Economics, 105(1): 155-165.

Carney, M. 2007. Minority family business in emerging markets: Organization forms and competitive advantage. Family Business Review, 20(4): 289-300.

Cennamo, C., Berrone, P., Cruz, C., \& Gomez-Mejia, L. R. 2012. Socioemotional wealth and proactive stakeholder engagement: Why family-controlled firms care more about their stakeholders. Entrepreneurship Theory and Practice, 36(6): 1153-1173.

Chang, S.-J., \& Shim, J. 2016. When does transitioning from family to professional management improve firm performance? Strategic Management Journal, 36(9): 1297-1316.

Chu, W. 2011. Family ownership and firm performance: Influence of family management, family control, and firm size. Asia Pacific Journal of Management, 28(4): 833-851.

Chua, J. H., Chrisman, J. J., \& Sharma, P. 2003. Succession and nonsuccession concerns of family firms and agency relationship with nonfamily managers. Family Business Review, 16(2): 89-107.

Chua, J. H., Chrisman, J. J., \& Steier, L. P. 2003. Extending the theoretical horizons of family business research. Entrepreneurship Theory and Practice, 27(4): 331-338.

Claessens, S., Djankov, S., Fan, J. P. H., \& Lang, L. H. P. 2002. Disentangling the incentive and entrenchment effects of large shareholdings. Journal of Finance, 57(6): 2741-2772.

Claessens, S., Djankov, S., \& Lang, L. H. P. 2000. The separation of ownership and control in East Asian corporations. Journal of Financial Economics, 58(1-2): 81-112.

Colquitt, J. A. 2001. On the dimensionality of organizational justice: A construct validation of a measure. Journal of Applied Psychology, 86(3): 386-400.

Colquitt, J. A., Scott, B. A., Rodell, J. B., Long, D. M., Zapata, C. P., Conlon, D. E., \& Wesson, M. J. 2013. Justice at the millennium, a decade later: A meta-analytic test of social exchange and affect-based perspectives. Journal of Applied Psychology, 98(2): 199-236.

Cropanzano, R., \& Mitchell, M. S. 2005. Social exchange theory: An interdisciplinary review. Journal of Management, 31(6): 847-900.

Daily, C. M., \& Dollinger, M. J. 1992. An empirical examination of ownership structure in family and professionally managed firms. Family Business Review, 5(2): 117-136. 
Datta, D. K., Guthrie, J. P., \& Wright, P. M. 2005. Human resource management and labor productivity: Does industry matter? Academy of Management Journal, 48(1): 135-145.

De Massis, A., Kotlar, J., Campopiano, G., \& Cassia, L. 2015. The impact of family involvement on SMEs' performance: Theory and evidence. Journal of Small Business Management, 53(4): $924-948$.

Delery,J. E., \& Shaw, J. D. 2001. The strategic management of people in work organizations: Review, synthesis and extension. Research in Personnel and Human Resource Management, 20: 165-197.

Dyer, W. G. 2006. Examining the 'family effect' on firm performance. Family Business Revieze, 19(4): 253-273.

Ensley, M. D., \& Pearson, A. W. 2005. An exploratory comparison of the behavioral dynamics of top management teams in family and nonfamily new ventures: Cohesion, conflict, potency, and consensus. Entrepreneurship: Theory and Practice, 29(3): 267-284.

Ewing, D. W. 1965. Is nepotism so bad? Harvard Business Revieze, 43: 23-32.

Fan, G., Wang, X. L., \& Zhu, H. P. 2011. NERI INDEX of marketization of China's provinces 2011 report. Beijing: Economics Science Press.

Fenton-O'Creevy, M. 1998. Employee involvement and the middle manager: Evidence from a survey of organizations. Journal of Organizational Behavior, 19(1): 67-84.

Floyd, S. W., \& Wooldridge, B. 1994. Dinosaurs or dynamos? Recognizing middle management's strategic role. Academy of Management Journal, 8(4): 47-57.

Floyd, S. W., \& Wooldridge, B. 1997. Middle management's strategic influence and organizational performance. Journal of Management Studies, 34(3): 465-485.

Fredrickson, J. W., \& Mitchell, T. R. 1984. Strategic decision processes: Comprehensiveness and performance in an industry with an unstable environment. Academy of Management Journal, 27(2): 399-423.

Gerhart, B. 1990. Voluntary turnover and alternative job opportunities. Journal of Applied Psychology, 75(5): 467-476.

Gomez-Mejia, L. R., Nunez-Nickel, M., \& Gutierrez, I. 2001. The role of family ties in agency contracts. Academy of Management Journal, 44(1): 81-95.

Guth, W. D., \& Macmillan, I. C. 1986. Strategy implementation versus middle management selfinterest. Strategic Management Journal, 7(4): 313-327.

Habbershon, T. G., Williams, M., \& MacMillan, I. C. 2003. A unified systems perspective of family firm performance. Journal of Business Venturing, 18(4): 451-465.

Harris, D., Martinez, J. I., \& Ward, J. L. 1994. Is strategy different for the family-owned business? Family Business Revieze, 7(2): 159-174.

He, X., Song, L., Zhu, H., \& Li, X. 2014. Why does the family firm want to let go? The perception of the system environment, the political status, and the succession intention of China's family firms' entrepreneurs. Management World, 2: 90-101.

Hofmann, D. A., \& Gavin, M. B. 1998. Centering decisions in hierarchical linear models: Implications for research in organizations. Journal of Management, 24(5): 623-641.

Hom, P. W., \& Griffeth, R. W. 1995. Employee turnover. Cincinnati, OH: South-Western Pub.

Huselid, M. A. 1995. The impact of human resource management practices on turnover, productivity, and corporate financial performance. Academy of Management Journal, 38(3): 635-672.

Iverson, R. D., \& Zatzick, C. D. 2011 . The effect of downsizing labor on productivity: The value of showing consideration for employees' morale and welfare in high-performance work systems. Human Resource Management, 50(1): 29-44.

Jaskiewicz, P., \& Uhlenbruck, K. 2013. Is nepotism good or bad? Types of nepotism and implications for knowledge management. Family Business Revieze, 26(2): 121-139.

Jensen, M. C., \& Meckling, W. H. 1976. Theory of the firm: Managerial behavior, agency cost, and ownership structure. Journal of Financial Economics, 3(4): 305-360.

Karra, N., Tracey, P., \& Phillips, N. 2006. Altruism and agency in the family firm: Exploring the role of family, kinship, and ethnicity. Entrepreneurship Theory and Practice, 30(6): 861-877.

Khwaja, A. I., \& Mian, A. 2005. Do lenders favor politically connected firms? Rent provision in an emerging financial market. The Quarterly Journal of Economics, 120(4): 1371-1411.

Kimberly, J. R. 1976. Organizational size and the structural perspective: A review, critique, and proposal. Administrative Science Quarterly, 21(4): 517-597.

Lee, J., \& Miller, D. 1996. Strategy, environment and performance in two technological contexts: Contingency theory in Korea. Organization Studies, 17(5): 729-750. 
Lee, K. S., Lim, G. H., \& Lim, W. S. 2003. Family business succession: Appropriation risk and choice of successor. Academy of Management Revieze, 28(4): 657-666.

Lee, T. H., Gerhart, B., Weller, I., \& Trevor, C. O. 2008. Understanding voluntary turnover: Pathspecific job satisfaction effects and the importance of unsolicited job offers. Academy of Management Journal, 51(4): 651-671.

Li, J., Zhou, C., \& Zajac, E. J. 2009. Control, collaboration, and productivity in international joint ventures: Theory and evidence. Strategic Management Journal, 30(8): 865-884.

Li, Q., \& Zhang, J. 2010. Institutional antecedent and characteristics of top executives: An empirical study. Management World, 10: 110-121.

Liang, J., Chen, S., \& Ge, Q. 2010. Political participation, governance structure and corporate philanthropy in Chinese private sector. Management World, 7: 109-118.

Maury, B. 2006. Family ownership and firm performance: Empirical evidence from Western European corporations. Journal of Corporate Finance, 12(2): 321-341.

McConaughy, D. L., Matthews, C. H., \& Fialko, A. S. 2001. Founding family controlled firms: Performance, risk, and value. Journal of Small Business Management, 39(1): 31-49.

McConville, T., \& Holden, L. 1999. The filling in the sandwich: HRM and middle managers in the health sector. Personnel Revieze, 28(5/6): 406-424.

Mitchell, T. R., Holtom, B. C., Lee, T. W., Sablynski, C. J., \& Erez, M. 2001. Why people stay: Using job embeddedness to predict voluntary turnover. Academy of Management Journal, 44(6): $1102-1122$.

Peiser, R. B., \& Wooten, L. M. 1991. Lite-cycle changes in small familv businesses. In C. E. Aronoff \& I. L. Ward (Eds.), Family business sourcebook: 430-441. Detroit: Omnigraphics.

Poza, E. F., Alfred, T., \& Maheshawi, A. 1997. Stakeholder perceptions of culture and management practices in family and family firms-A preliminary report. Family Business Revieze, 10(2): $135-155$.

Schulze, W. S., Lubatkin, M. H., \& Dino, R. N. 2003. Toward a theory of agency and altruism in family firms. Journal of Business Venturing, 18(4): 473-490.

Schulze, W. S., Lubatkin, M. H., Dino, R. N., \& Buchholtz, A. K. 2001. Agency relationships in family firms: Theory and evidence. Organization Science, 12(2): 99-166.

Sciascia, S., \& Mazzola, P. 2008. Family involvement in owners and management: Exploring nonlinear effects on performance. Family Business Revieze, 21(4): 331-345.

Silva, F., \& Majluf, N. 2008. Does family ownership shape performance outcomes. Journal of Business Research, 61(6): 609-614.

Songini, L., \& Gnan, L. 2015. Family involvement and agency cost control mechanisms in family small and medium-sized enterprises.Journal of Small Business Management, 53(3): 748779.

Steen, A., \& Baldwin, K. 2015, October 27. Family business in China - Is there a succession crisis? Social Media Today RSS. [Cited 9 November 2016]. Available from URL: http://www. familyownedbusinessadvisors.com/2015/10/family-business-in-china/

Tsao, C. W., Ghen, S. J., Lin, C. S., \& Hyde, W. 2009. Founding-family ownership and firm performance: The role of high-performance work systems. Family Business Revieze, 22(4): 319-332.

Urwick, L. F. 1922. The manager's span of control. Harvard Business Revieze, 34: 39-47.

Villalonga, B., \& Amit, R. 2006. How do family ownership, control and management affect firm value? Journal of Financial Economics, 80(2): 385-417.

Whyte, M. K. 1996. The Chinese family and economic development: Obstacle or engine? Economic Development and Cultural Change, 45(1): 1-30.

Yammeesri,J., \& Lodh, S. C. 2004. Is family ownership a pain or gain to firm performance? Journal of Financial Economics, 80: 385-417.

Zhang, J., \& Ma, H. 2008. Adoption of professional management in Chinese family business: A multilevel analysis of impetuses. Asia Pacific Journal of Management, 26(1): 119-139.

Qiongjing Hu (huqiongjing@pku.edu.cn) is a PhD candidate at Guanghua School of Management, Peking University. Currently, his research focuses on leadership, team, and creativity. His research has appeared in Academy of Management Fournal, Human Relations, and Journal of Vocational Behavior. 
Yanlong Zhang (yanlong.zhang@gsm.pku.edu.cn) is an Associate Professor at Guanghua School of Management at Peking University. He received his BA and MA in sociology from Peking University in 2002 and 2005, and received his $\mathrm{PhD}$ in sociology from Duke University in 2012. His research interests include organization theory, social networks and social capital, corporate social responsibility, entrepreneurship, and policy diffusion. He published over twenty articles in leading sociology and management journals such as Academy of Management Annals, Journal of Business Venturing, Social Networks, Human Resource Management, and Management and Organization Review.

Jingjing Yao (j.yao@ieseg.fr) is an assistant professor of International Negotiations at IÉSEG School of Management (LEM-CNRS 9221). He received a $\mathrm{PhD}$ in Organization Management from Peking University. His research interests include negotiation, trust, and cross-cultural studies. His research has appeared in Organizational Behavior and Human Decision Processes, Journal of Organizational Behavior, and Management and Organization Review.

Manuscript received: November 9, 2016

Final version accepted: December 8, 2017 (number of revisions - 2)

Accepted by: $\quad$ Senior Editor Xiaowei Rose Luo 